\title{
STUDI KASUS PEMBELAJARAN LUAR JARINGAN PESERTA DIDIK KELAS VII SMPK CHRISTO REGI ENDE
}

\author{
Maria Elsensia Penu ${ }^{1}$, Adrianus Nasar ${ }^{2}$, Melkyanus B.U. Kaleka ${ }^{3}$ \\ ${ }^{1,2,3}$ Program Studi Pendidikan Fisika \\ Fakultas Keguraan dan Ilmu Pendidika Universitas Flores \\ email: mariaelsensi97@gmail.com
}

\begin{abstract}
ABSTRAK
Penelitian ini bertujuan untuk mengetahui keefektifan pembelajaran dari rumah secara luar jaringan pada mata pelajaran Ilmu Pengetahuan Alam peserta didik kelas VII Sekolah Menengah Pertama Katolik Christo Regi. Pendekatan yang digunakan dalam penelitian adalah pendekatan deskriptif dengan jenis penelitian kualitatif fenomenologi. Ciri penelitian kualitatif adalah bersifat deskriptif dimana data yang dikumpulkan berupa katakata dan juga gambar. Subyek dari penelitian ini adalah satu orang guru dan 25 orang peserta didik kelas VII. Teknik pengumpulan data menggunakan teknik wawancara, observasi, kuesioner dan dokumentasi. Data-data yang sudah terkumpul, kemudian dianalisis secara deskriptif dengan tahapan meliputi penjaringan data, klasifikasi, verifikasi dan penarikan kesimpulan. Hasil penelitian menunjukkan bahwa pelaksanaan proses pembelajaran luar jaringan yang terjadi adalah; 1) perencaan pembelaajran berjalan cukup efektif; 2) pelaksanaan pembelajaran berjalan cukup efektif; 3) pelaksanaan evaluasi berjalan efektif. dan 4) Hasil belajar siswa cukup baik.
\end{abstract}

\section{Kata Kunci: Pembelajaran, Luar Jaringan}

\section{ABSTRACT}

This study aims to determine the effectiveness of online learning from home on the subject of Natural Sciences for seventh grade students of Christo Regi Catholic Junior High School. The approach used in this research is a descriptive approach with a qualitative phenomenological type of research. Characteristics of qualitative research is descriptive in which the data collected in the form of words and pictures. The subjects of this study were one teacher and 25 students of class VII. Data collection techniques using interview techniques, observation, questionnaires and documentation. The data that has been collected is then analyzed descriptively with stages including data collection, classification, verification and drawing conclusions. The results showed that the implementation of the learning process outside the network that occurred were; 1) lesson planning is running quite effectively; 2) the implementation of learning runs quite effectively; 3) the evaluation is running effectively. and 4) student learning outcomes are quite effective.

Keywords: Learnin, offline 


\section{PENDAHULUAN}

Kegiatan pembelajaran merupakan faktor penting dalam mewujudkan keberhasilan pendidikan. Kegiatan pembelajaran adalah proses sistematis yang dilakukan guru dalam mewujudkan proses pembelajaran yang efektif dan efisien, dimulai dari perencanaan, pelaksanaan dan evaluasi (Aqib \& Amrullah, 2017). Saat ini dunia sedang dilanda wabah virus Covid-19. Kondisi ini sangat berdampak terhadap dunia pendidikan. Selama masa pandemi covid-19, pelaksanaan pendidikan di Indonesia mengalami perubahan yang sangat signifikan dalam pelaksanaan proses pembelajaran (Windhiyana, 2020).

Proses pembelajaran dilaksanakan dengan sistem belajar dari rumah atau sistem luar jaringan (luringan) dan dalam jaringan (daring). Sesuai peraturan kementrian pendidikan dan kebudayaan (kemendikbud), dikeluarkan Surat Edaran Nomor 15 Tahun 2020 yang memuat pedoman penyelenggaraan belajar dari rumah dalam masa darurat penyebaran covid-19 (Kemendikbud, 2020).

Terlaksananya proses pembelajaran bermutu merupakan tanggung jawab besar seorang guru dengan terus berusaha memberikan pembelajaran yang dapat diterima dan dipahami dengan baik oleh peserta didik. Proses pembelajaran secara daring merupakan pilihan yang wajib dilaksakan saat ini. Pilihan ini juga sangat bergantung pada kesiapan guru dan peserta didik dalam memanfaatkan teknologi, kesiapan sekolah dalam menyediakan fasilitas yang mendukung, serta didukung dengan ekonomi yang baik (Sadikin \& Hamidah, 2020). Banyak cara yang dapat dilakukan guru agar terwujudnya proses pembelajaran dimasa Covid-19, salah satunya memanfaatkan teknologi informasi dan komunikasi menggunakan internet, serta aplikasi pendukung lainnya seperti whatsapp, zoom, facebook, instagram, google classroom dan lain sebagainya (Arizona et al., 2020).

Salah satu kendala yang menghambat proses pembelajaran secara daring (dalam jaringan) atau pembelajaran online adalah wilayah atau daerah yang tidak memiliki jaringan internet (Hasanah et al., 2020; Kaleka et al., 2020). Sehingga pelaksanaan proses pembelajaran tetap dilakukan secara luring. Kondisi ini dialami oleh beberapa sekolah yang ada di Kabupaten Ende, dan salah satunya adalah SMPK Christo Regi.

Pelaksanaan pembelajaran luar jaringan dilakukan sebagai salah satu upaya untuk tetap mewujudkan tujuan pendidikan di Indonesia di tengah pandemi Covid19, serta upaya pencegahan penyebaran virus Covid-19. Pademi Covid-19 ini membuat sistem pembelajaran di sekolah dipaksa berubah secara drastis dari pertemuan tatap muka dengan waktu yang tepat menjadi pembelajaran secara singkat. Pelaksanaan pembelajaran ini berlangsung dari jenjang sekolah dasar hingga perguruan tinggi. Pada satuan pendidikan setingkat SMPK Christo Regi pelaksanaan pembelajaran berbasis luar jaringan masih terbilang jarang atau bahkan belum pernah dilaksanakan. Sehingga penerapan pembelajaran luar jaringan di SMPK Christo Regi pasti akan menemui berbagai kendala. Kendala yang paling menonjol adalah perubahan kebiasaan yang terjadi pada diri siswa, dimana pada awalnya diterima dengan baik, antusias karena kegiatan akan dilakukan di rumah, namun seiring berjalannya waktu akan menimbulkan sebuah kejenuhan dalam diri siswa karena melakukan sebuah rutinitas yang sama setiap hari. Selain itu, intensitas guru dalam menyampaikan sebuah materi dalam salah satu mata pelajaran menjadi berkurang dan kurang masksimal, waktu yang digunakan juga sangat terbatas serta minimnya sarana prasarana (Firman \& Rahayu, 2020). Jika penyampaian materi yang biasanya dilakukan di 
sekolah bukan dengan metode ceramah, akan sedikit mudah diterapkan dalam pembelajaran luar jaringan, sebaliknya ada mata pelajaran yang bila tidak disampaikan dengan metode ceramah akan sulit dipahami siswa, dan kemungkinan sulit untuk diterapkan pembelajaran luar jaringan dalam mata pelajaran tersebut, seperti mata pelajaran IPA.

Dari hasil wawancara dengan guru IPA di SMPK Christo Regi pembelajaran luar jaringan yang terjadi di SMPK Christo Regi ada 4 zona yang ditentukan dari sekolah yaitu antara lain, ada zona Nangaba, zona Watusipi, zona Mbomba dan zona Kota. Di zona kota pembelajaran dilakukan sebulan sekali dan terjadi pada minggu ke 3, sedangkan di zona luar kota di lakukan pada minggu pertama. Guru akan mengunjungi siswa di setiap tanggal yang sudah di tentukan oleh sekolah dan siswa akan menyiapkan tempat untuk berlangsungnya kegiatan proses belajar mengajar agar kegiatan belajar mengajar dapat berjalan dengan lancar.

\section{METODE}

Pendekatan yang digunakan dalam penelitian adalah pendekatan deskriptif dengan jenis penelitian kualitatif fenomenologi. Ciri penelitian kualitatif adalah bersifat deskriptif dimana data yang dikumpulkan berupa kata-kata, gambar, dan bukan angka (Sugiyono, 2019). Menurut Moleong (2014), penelitian kualitatif adalah penelitian yang bermaksud untuk memahami fenomena tentang apa yang dialami oleh subjek penelitian misalnya, motivasi, sikap, persepsi, dan lain-lain, baik secara holistik dan deskriptif dalam bentuk kata-kata dan bahasa, dengan memanfaatkan berbagai metode ilmiah.

Subyek dari penelitian ini adalah satu orang guru mata pelajaran IPA dan siswa SMPK Christo Regi Ende kelas VII yang berjumlah 25 orang. Obyek dari penelitian ini adalah pembelajaran luar jaringan pada siswa kelas VII di SMPK Christo Regi. Darmawan (2014), mengungkapkan bahwa teknik pengumpulan data merupakan cara atau alat yang digunakan peneliti dalam mengumpulkan data. Data dapat berupa data primer dan data sekunder (Khairinal, 2016). Pengumpulan data dalam penelitian ini menggunakan teknik wawancara, observasi, kuesioner dan dokumentasi..

Data-data yang sudah terkumpul dalam penelitian ini kemudian dianalisis. Menurut Bogdan, proses analisis data adalah proses mencari dan menyusun secara sistematis data yang diperoleh dari hasil wawancara, catatan lapangan, dan data lain sehingga mudah dipahami dan temuannya dapat diinformasikan kepada orang lain (Sugiyono, 2019). Tahapan dalam analisis data kualitatif antara lain (Sugiono, 2014);

1. Melakukan pencatatan lapangan

2. Mengumpulkan, memilah-milah, mengklasifikasikan, dan mensintesiskan.

3. Mencari pola dan hubungan-hubungan untuk menarik kesimpulan

\section{HASIL DAN PEMBAHASAN}

1. Persiapan dalam melaksanakan pembelajaran luar jaringan.

Berdasarkan hasil observasi menunjukkan bahwa persiapan pembelajaran luar jaringan pada mata pelajaran IPA siswa kelas VII SMP Swasta Katolik Christo Regi cukup efektif untuk siswa kelas VII, karena persiapan yang dilakukan sudah sesuai dengan apa yang diinformasikan guru serta sesui dengan kebijakan yang dibuat 
pemerintah untuk menjaga jarak selama proses pembelajaran berlangsung. Siswa menyusun kursi dengan jarak 1 meter dengan mejanya masing-masing sehingga tidak ada kontak fisik selama proses pembelajaran, dan lokasi yang digunakan siswa sangat nyaman dan kondusif untuk proses belajar.

Proses pembelajaran dilakukan dengan sistem tatap muka terbatas yang terjadi di rumah siswa, yang terbagi dalam 4 zona dengan jumlah siswa setiap zona kurang lebih $5-6$ orang. Lama proses pembelajaran kurang dari satu jam. Setiap zona melaksanakan proses pembelajaran sebanyak satu kali pertemuan dalam satu minggu.

2. Pelaksanaan pembelajaran luar jaringan

Tabel 1. Hasil Wawancara dan Kuesioner

\begin{tabular}{|c|c|c|c|}
\hline Variabel & Indikator & $\begin{array}{c}\text { Hasil Wawancara } \\
\text { Guru }\end{array}$ & Hasil Kuesioner \\
\hline \multirow{3}{*}{$\begin{array}{l}\text { Proses } \\
\text { pelaksanaan } \\
\text { pembelajaran }\end{array}$} & $\begin{array}{l}\text { 1. Membuka } \\
\text { pelajaran }\end{array}$ & $\begin{array}{l}\text { Wawancara dilakukan } \\
\text { terhadap guru mata } \\
\text { pelajaran IPA kelas VII } \\
\text { SMPK Christo Regi } \\
\text { Ende, hasil wawancara } \\
\text { menunjukkan bahwa } \\
\text { dalam kegiatan } \\
\text { membuka pelajaran } \\
\text { merupakan faktor yang } \\
\text { cukup penting untuk } \\
\text { membangkitkan } \\
\text { semangat siswa dalam } \\
\text { memahami materi yang } \\
\text { akan di pelajari. }\end{array}$ & $\begin{array}{l}\text { Berdasarkan hasil angket, dari } \\
25 \text { orang siswa di SMPK } \\
\text { Christo Regi, yang menjawab } \\
\text { guru IPA sudah melaksanakn } \\
\text { kegiatan membuka } \\
\text { pembelajaran sebanyak } 80 \% \text {. }\end{array}$ \\
\hline & 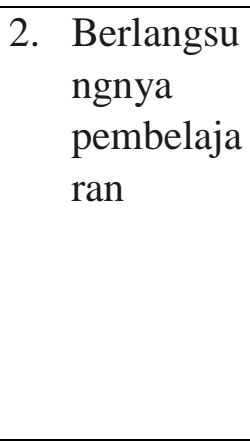 & $\begin{array}{l}\text { Berdasarkan hasil } \\
\text { wawancara bahwa siswa } \\
\text { aktif dalam memahami } \\
\text { materi, meskipun ada } \\
\text { sebagian siswa yang } \\
\text { tidak terlalu dominan } \\
\text { selama proses kegiatan } \\
\text { belajar mengajar } \\
\text { berlangsung }\end{array}$ & $\begin{array}{l}\text { Berdasarkan hasil angket dari } \\
25 \text { orang siswa yang cukup } \\
\text { aktif dalam memahami materi } \\
\text { selama proses pembelajaran } \\
\text { berlangsung sebanyak } 50 \%\end{array}$ \\
\hline & $\begin{array}{ll}\text { 3. } & \text { Akhir } \\
& \text { pembelaja } \\
& \text { ran }\end{array}$ & $\begin{array}{l}\text { Dari hasil wawancara } \\
\text { guru IPA menyatakan } \\
\text { bahwa dalam kegiatan } \\
\text { menutup pembelajaran } \\
\text { selalu diakhiri dengan } \\
\text { menarik kesimpulan } \\
\text { serta siswa akan } \\
\text { diberikan tugas untuk } \\
\text { lebih menguji } \\
\text { kepahaman siswa dalam } \\
\text { memahami materi. }\end{array}$ & $\begin{array}{l}\text { Hasil pengisian angket dari } 25 \\
\text { orang siswa sebanyak } 70 \% \text {. }\end{array}$ \\
\hline
\end{tabular}




\section{Evaluasi Pembelajaran Luar Jaringan}

Berdasarkan hasil dokumentasi tentang nilai-nilai yang didapatkan siswa cukup efektif. Siswa mendapatkan nilai-nilai dari awal mengikuti pembelajaran sampai akhir pembelajaran dan pada saat siswa mengikuti ujian midel atau ujian akhir semester. Terdapat beberapa siswa yang memperoleh nilai masih di bawah KKM, walaupun sebelumnya dalam pembelaajran secara tatap muka normal nilai siswa masih cukup baik. Terdapat banyak kendala yang dihadapi guru dan peserta didik dalam menghadapi proses pembelajaran secara luring, diantaranya adalah keterbatasan media yang digunakan, waktu yang singkat dan hanya dilakukan satu kali tatap muka dalam satu minggu. Dari beberapa penelitian sebelumnya memberikan informasi bahwa terjadi penurunan motivasi dan prestasi siswa selama massa pandemic Covid-19 (Deno et al., 2020; Hasanah et al., 2020; Pujilestari, 2020).

\section{Hasil Belajar}

Berdasarkan hasil wawancara dengan guru pembelajaran luar jaringan cukup efektif. Dilihat dari nilai-nilai yang didapatkan siswa pada saat mengikuti ujian tengah semester, hasilnya memuaskan dan memenuhi standar kompetensi yang ditentukan. Hal ini disebabkan karena dalam pelaksanaan pembelajaran luar jaringan guru selalu memantau siswa dan selalu memberikan motivasi kepada siswa sehingga siswa dapat mengerjakan tugas-tugas atau soal-soal yang diberikan guru dengan sungguh-sungguh dan semangat (Susilawati \& Sari, 2019).

Berdasarkan hasil wawancara dan kuesioner diambil kesimpulan, bahwa di SMPK Christo Regi pada kelas VII telah menjalankan pembelajaran dengan menggunakan pembelajaran luar jaringan. Pada awal-awal pertemuan siswa masih merasa kebingungan dengan pembelajaran luar jaringan yang cukup berbeda dari sebelumnya. Dilihat dari segi waktu yang mana harus dikelola dengan baik mengingat pembelajaran luar jaringan yang cukup singkat. Sedangkan di teknik observasi siswa menepatkan posisi dan menyiapkan diri di lokasi yang telah disepakati bersama sehingga pembelajaran dapat berlangsung dengan baik, nyaman, dan kondusif.

Proses evaluasi yang dilaksanakan untuk siswa kelas VII SMPK Christo Regi yaitu melalui tugas-tugas yang dikumpulkan. Dimana tugas-tugas yang dikumpulkan akan diberikan nilai untuk menentukan nilai keberhasilan siswa setelah mengikuti proses belajar dalam setiap kegiatan yang dilakukan dalam proses belajar mengajar baik pada awal kegiatan maupun pada akhir kegiatan dan pada akhir semester. Pada hasil belajar dan observasi di SMPK Christo Regi hasil belajar didapatkan dari nilai-nilai yang telah dikumpulkan dari hasi evaluasi secara keseluruhan dan siswa cukup efektif dalam mengikuti pembelajaran luar jaringan ini.

\section{PENUTUP}

Berdasarkan data penelitian dan pembahasan yang menjadi fokus penelitian adalah keefektivan pembelajaran luar jaringan yang telah diuraikan sebelumnya, maka dapat diambil kesimpulan bahwa pelaksanaan proses pembelajaran yang terjadi adalah; 1) perencaan pembelaajran berjalan cukup efektif; 2) pelaksanaan pembelajaran berjalan cukup efektif; 3) pelaksanaan evaluasi berjalan efektif. 4) Hasil belajar siswa cukup baik 


\section{UCAPAN TERIMA KASIH}

Terima kasih yang sebesar-besarnya bagi pihak Sekolah Menengan Pertama Katolik Christo Regi yang sudah banyak membantu dalam memberikan informasi sehingga pelaksanaan penelitian ini dapat berjalan dengan baik. Terima kasih juga kepada LPPM Universitas Flores yang telah mendukung pelaksanaan penelitian ini. Kiranya Tuhan selalu memberkati kita semua.

\section{DAFTAR PUSTAKA}

Aqib, Z., \& Amrullah, A. (2017). Pedoman pendidikan budaya dan karakter bangsa. Nuansa Cendekia.

Arizona, K., Abidin, Z., \& Rumansyah, R. (2020). Pembelajaran Online Berbasis Proyek Salah Satu Solusi Kegiatan Belajar Mengajar Di Tengah Pandemi Covid-19. Jurnal Ilmiah Profesi Pendidikan.

Deno, M. E., Bili, M., Kaleka, U., Harso, A., Studi, P., Fisika, P., \& Keguruan, F. (2020). AKTIVITAS BELAJAR MAHASISWA UNIVERSITAS FLORES PADA MASA PANDEMIK CORONA VIRUS DISEASE 19. OPTIKA: Jurnal Pendidikan FisikaJurnal Pendidikan Fisika, 4(2), 110-116. https://doi.org/https://doi.org/10.37478/optika.v4i2.702

Firman, F., \& Rahayu, S. (2020). Pembelajaran Online di Tengah Pandemi Covid-19. Indonesian Journal of Educational Science (IJES). https://doi.org/10.31605/ijes.v2i2.659

Hasanah, A., Sri Lestari, A., Rahman, A. Y., \& Danil, Y. I. (2020). Analisis Aktivitas Belajar Daring Mahasiswa Pada Pandemi COVID-19. Karya Tulis Ilmiah (KTI) Masa Work From Home (WFH) Covid-19 UIN Sunan Gunung Djati Bandung Tahun 2020.

Kaleka, M. B. U., Ika, Y. E., \& Deno, M. E. (2020). Stusi Kasus Manajemen Sistem Pembelajaran Google Classroom Pada Perkuliahan Alat Ukur Fisika. Jurnal $\begin{array}{llll}\text { Pendidikan Sains } & \text { (JPS), } & \text { 8(2), }\end{array}$ https://jurnal.unimus.ac.id/index.php/JPKIMIA/article/view/6022

Kemendikbud. (2020). Surat Edaran Sekretaris Jenderal No.15 Tahun 2020 Pedoman Pelaksanaan Belajar Dari Rumah Selama Darurat Bencana COVID-19 di Indonesia. Sekretariat Nasional SPAB (Satuan Pendidikan Aman Bencana), 15, 1-16

Khairinal. 2016. Menyusun Proposal, Skripsi, Tesis, dan Disertasi. Jambi: Salim Media Indonesia (Anggota IKAPI).

Moleong, Lexy J. 2014. Metodoli Penelitian Kualitatif. Bandung: PT. Remaja Rosdakarya. Pujilestari, Y. (2020). Dampak Positif Pembelajaran Online Dalam Sistem Pendidikan Indonesia Pasca Pandemi Covid-19. Adalah.

Sadikin, A., \& Hamidah, A. (2020). Pembelajaran Daring di Tengah Wabah Covid-19 ( Online Learning in the Middle of the Covid-19 Pandemic ). BIODIK: Jurnal Ilmiah Pendidikan Biologi.

Sugiono, P. D. (2014). Metode penelitian pendidikan pendekatan kuantitatif.pdf. In Metode Penelitian Pendidikan Pendekatan Kuantitatif, Kualitatif Dan R\&D.

Sugiyono. (2019). METODE PENELITIAN PENDIDIKAN. In Bandung:Alfabeta.

Susilawati, S., \& Sari, I. W. (2019). PEMBELAJARAN FISIKA BERBANTUKAN MEDIA SOSIAL FACEBOOK DAN DAMPAKNYA TERHADAP HASIL BELAJAR FISIKA. Jurnal Pendidikan Fisika. https://doi.org/10.24127/jpf.v7i1.1788

Windhiyana, E. (2020). DAMPAK COVID-19 TERHADAP KEGIATAN PEMBELAJARAN ONLINE DI PERGURUAN TINGGI KRISTEN DI INDONESIA. Perspektif Ilmu Pendidikan. https://doi.org/10.21009/pip.341.1 